\title{
LETRAMENTOS ACADÊMICOS E IDENTIDADES DOCENTES EM UM CURSO DE MESTRADO PROFISSIONAL EM LETRAS'
}

\section{ACADEMIC LITERACIES AND TEACHER IDENTITIES IN A MASTER'S COURSE IN LANGUAGE TEACHING}

Roberta Gleyciângela Souza Lopes²

RESUMO: Neste artigo, proponho uma análise das mudanças no letramento acadêmico e as suas implicaçōes no perfil identitário de professores(as) em formaçâo, fundamentando-me nos estudos sociais do Letramento (STREET, 1984; 2003; 2010; 2012) e nos estudos críticos do discurso (FAIRCLOUGH, 2001;2003). Para tanto, tomo por base dados qualitativos coletados entre professores(as) da educaçăo básica inscritos no Programa de Mestrado Profissional em Letras (Profletras). Os dados apontam que, após a inserçăo em práticas de letramento do mestrado profissional, ampliam-se as identidades docentes, com novas possibilidades de atuaçăo.

PALAVRAS CHAVE: letramentos acadêmicos; mudança discursiva; identidade docente.

ABSTRACT: In this paper, I propose an analysis of changes in academic literacies and their implications for teachers' identities, adopting social studies of literacy (STREET, 1984; 2003; 2010; 2012) and critical discourse studies (Fairclough, 2001; 2003). The qualitative data generation took place among teachers of primary education enrolled in a master's course in language teaching (Profletras), After the participants' insertion into the academic literacies of the course, their teacher identities widened with new possibilities for action.

KEY WORDS: academic literacy; discourse change; teacher identity

\section{APRESENTAÇÃO}

Este trabalho, inserido na área de Linguística Aplicada, manifesta especial interesse pela formaçáo de professores(as), com o objetivo de conhecer os letramentos que foram se constituindo dentro da nova realidade de um mestrado profissional em Letras e as identidades docentes que foram se reconfigurando nesse contexto. É objetivo desta pesquisa responder às seguintes questōes: Que imagens os mestrandos e mestrandas constroem sobre a própria formaçăo? Que mudanças podem ser percebidas no letramento acadêmico depois do ingresso nas práticas discursivas de letramento do

Este estudo resultou da dissertaçâo de Mestrado da autora, intitulada "Mudanças no letramento acadêmico: questóes de linguagem e identidade" (PPGL/UFC), orientada pela Professora Dra. Maria Izabel dos Santos Magalhăes.

2 Mestranda em Linguística pela Universidade Federal do Ceará (UFC) e graduada em Letras pela mesma universidade; professora da rede estadual de ensino do Ceará. 
Profletras? De que forma os eventos e práticas de letramento no contexto do Mestrado Profissional podem redefinir e reconstruir as identidades docentes?

A problemática que despertou o meu interesse como professora foi a ausência de uma qualificaçăo adequada para professores(as) nos programas de pós-graduaçáo acadêmica que, dirigindo-se à formaçăo de pesquisadores(as), nâo atendem, de maneira efetiva, às especificidades dos papéis profissionais (de professor/professora) a serem exercidos. Segundo Fisher (2005), a pós-graduaçăo stricto sensu, desde a sua gênese, é fortemente orientada à formaçấo de pesquisadores(as), enquanto a formaçăo de professores(as) nâo tem merecido espaço significativo nos cursos de mestrado e doutorado:

Nos cursos, conteúdos e métodos de pesquisa săo o foco do ensino. Portanto, há iniciaçăo à pesquisa nos mestrados e capacitaçáo para a pesquisa nos doutorados. A formaçăo do professor como profissional náo é incorporada aos currículos da maior parte dos cursos (p. 25).

Fica claro, portanto, que os cursos de pós-graduaçăo com orientaçăo acadêmica, em sua maioria, náo constituem espaços adequados para que os objetivos de formaçáo de professores(as) sejam alcançados. Os cursos de Mestrado Profissional (MP), por sua vez, objetivam minimizar a distância entre a universidade e as práticas docentes na escola e, portanto, săo alvo do meu interesse. Essa modalidade de ensino deve ser valorizada como uma experiência inovadora, capaz de contribuir para a renovaçáo da pós-graduaçăo brasileira, ao orientar o ensino para a aplicaçăo. Nâo se quer com isso afirmar que os mestrados profissionais sejam o futuro da academia e que deverâo substituir os mestrados acadêmicos, tornando-os obsoletos. Na verdade, o surgimento desses novos programas de MP nâo tem a finalidade de eliminar ou simplesmente substituir a pós-graduaçăo acadêmica, mas de permitir a oferta simultânea de uma nova forma de se produzir saber no País.

Nesse contexto, busco compreender os posicionamentos identitários dos sujeitos cursistas do Profletras, programa de formaçấo continuada que exige, além da formaçâo de pesquisadores(as), a formaçáo de professores(as), voltados(as) para a inovaçăo em sala de aula. A emergência desses programas de orientaçáo profissional representam um redimensionamento do papel da universidade, tornando-a mais disponível para a busca da soluçâo de problemas enfrentados por professores(as) do ensino básico, na conduçăo de classes superlotadas e heterogêneas.

\section{UM OLHAR SOBRE O CONTEXTO}

Tendo em vista o pouco impacto dos cursos de pós-graduaçăo stricto sensu no sistema escolar, em particular na sala de aula, a Coordenadoria de Aperfeiçoamento de Pessoal de Ensino Superior (Capes) constituiu, no ano 2000, uma comissấo que seria responsável por elaborar uma proposta de mestrado, distinta daquela até entăo existente, específica para atender às necessidades dos(as) professores(as) de Ensino Médio e Fundamental, bem como das licenciaturas. A proposta elaborada por essa comissáo foi intitulada "Mestrado (profissional) em Ensino" e data de 2001.0 mestrado em ensino, segundo o texto do documento, deve ter "caráter de preparaçăo profissional na área docente focalizando o ensino, a aprendizagem, o currículo, a avaliaçăo e o sistema escolar" (MOREIRA, 2004, pp. 133-134). 
A expectativa era incentivar o surgimento de propostas de cursos de mestrado profissional em disciplinas de diferentes áreas de conhecimento, mas, na prática, até o ano de 2004, somente foram apresentados e aprovados projetos na Área de Ensino de Ciências e Matemática. Até entăo a concepçăo dominante era de que a área de Letras năo tinha relaçâo com essa modalidade de pós-graduaçấo, no entanto essa concepçâo mudou com o reconhecimento da necessidade de capacitar os professores de Língua Portuguesa da educaçăo básica. A história de implementaçáo do Programa de Mestrado Profissional em Letras - Profletras, curso oferecido em rede nacional, iniciou em abril de 2012, com o encaminhamento da proposta do curso à Capes, que foi aprovada com nota 4 pelo Conselho Técnico-Científico da Coordenadoria. O primeiro processo seletivo aconteceu em 2013 e, já na primeira ediçăo do programa, o número de 13 mil candidatos(as) inscritos(as) comprova a carência na formaçăo de professores de letras no país e a importância dessa iniciativa.

Quanto à modalidade de ensino, a página oficial do projeto o apresenta como um curso semipresencial, com parte das atividades a serem realizadas de modo presencial, com oferta simultânea em todas as unidades do País, e parte a ser desenvolvida por meio do uso da metodologia da educaçâo a distância, porém na unidade observada, a modalidade de ensino tem sido exclusivamente a presencial. O projeto conta com a participaçâo de Instituiçôes de Ensino Superior, no contexto da Universidade Aberta do Brasil (UAB), um sistema integrado por universidades públicas que oferece cursos de nível superior para camadas da populaçăo que têm dificuldade de acesso à formaçăo universitária, por meio do uso da metodologia da educaçáo a distância. A sede do Profletras fica na Universidade Federal do Rio Grande do Norte e o programa reúne, atualmente, 42 universidades públicas das cinco regiōes brasileiras, totalizando 49 unidades, tendo em vista que há seis universidades que oferecem mais de uma unidade.

No ano de 2016, ocorreu a quarta ediçấo do Exame Nacional de Acesso, baseado em prova escrita, com questóes objetivas e discursivas, com a finalidade de avaliar as habilidades de leitura e de escrita. O curso é destinado a professores(as) em exercício, por isso uma das características é a flexibilidade de horário, pois os(as) mestrandos(as) devem conciliar as aulas com o exercício docente. O colegiado local de cada unidade que integra a Rede determina o dia em que as aulas serâo ministradas, podendo ocorrer de segunda a sábado. Na unidade observada, as aulas ocorrem somente às sextas-feiras.

Ao falar das condiçôes gerais para os Mestrados Profissionais em ensino, o documento "Mestrado (profissional) em ensino" (2004, p. 135) postula:

\footnotetext{
Os professores mestrandos deverăo ter alguma forma de apoio (reduçăo de carga horária e/ ou bolsa, por exemplo) que viabilize sua participaçăo; sabe-se que os professores em exercício no ensino básico ou em instituiçóes năo estatais têm elevada carga horária, e é para eles que o mestrado em ensino se destina primordialmente, de modo que é indispensável viabilizar sua participaçăo năo só por meio de horários especiais ou ensino a distância.
}

Percebemos, porém, na prática, que essas condiçóes năo se concretizam atualmente, faltando incentivos à participaçăo desses(as) professores(as). A reduçăo de carga horária para a formaçăo em MP năo está prevista nos sistemas municipal e estadual de ensino em que os(as) mestrandos(as) da unidade observada atuam. Esse fato origina muitas queixas pela falta de tempo para dedicaçâo aos estudos. Quanto à concessâo 
de bolsas, houve pagamento regular para as duas primeiras turmas, mas a $3^{a}$ turma, iniciada em 2016, nâo recebeu o benefício. Todos esses desafios săo frequentemente relatados nas entrevistas.

O objetivo do Programa de Mestrado Profissional em Letras é capacitar professores(as) de Língua Portuguesa para o exercício da docência no Ensino Fundamental, com o intuito de contribuir para a melhoria da qualidade do ensino no País. Isso impóe maiores exigências sobre os(as) mestrandos(as) que, para a obtençâo do título de mestre, devem desenvolver uma proposta de atividade voltada para o ensino e apresentar, em seu trabalho de conclusâo, o resultado do desenvolvimento dessa atividade. Defendo que as exigências sobre eles/elas săo maiores, porque precisam desenvolver uma pesquisa com retorno social em um contexto nem sempre favorável, a julgar pelas dificuldades relatadas, tais como impossibilidade de afastamento, falta de tempo para as leituras, intransigência de gestores(as) nas escolas.

Para conhecer os letramentos e as identidades relacionadas a esse Programa, adotei alguns procedimentos de geraçấo e análise de dados que descrevo a seguir.

\section{PROCEDIMENTOS METODOLÓGICOS E CATEGORIAS DE ANÁLISE}

Fairclough (2003) sugere a combinaçâo da Análise de Discurso Crítica (ADC) com a pesquisa de natureza etnográfica, por reconhecer os limites de uma análise somente textual e a necessidade de analisar conjuntamente outros elementos da prática social. Magalhăes (2006), corroborando essa ideia, defende que os textos, como elementos de uma prática social, săo melhor compreendidos no interior dessas práticas. Desse modo, os textos selecionados neste estudo foram gerados em entrevistas individuais ocorridas entre os meses de janeiro a junho de 2016 - com oito cursistas do Profletras. Além disso, realizei observaçăo participante em duas disciplinas do Programa.

Em relaçăo à entrevista, selecionei como participantes mestrandos(as) de diferentes momentos do curso: quatro participantes da $2^{\mathrm{a}}$ turma, iniciada em 2015, e quatro participantes da $3^{a}$ turma, iniciada em 2016. Os(as) quatro participantes selecionados na segunda ediçâo do programa já cursaram um ano de disciplinas, cumpriram a etapa de qualificaçăo e estăo cursando o último ano do mestrado. Já os(as) participantes da terceira turma iniciaram sua trajetória na pós-graduaçâo em 2016.1. Essas entrevistas foram gravadas em áudio, transcritas e analisadas em conformidade com as categorias que discutirei logo mais. Na transcriçâo das entrevistas, os nomes dos(as) participantes da pesquisa foram preservados, de modo a garantir-lhes a confidencialidade das informaçōes; os(as) participantes foram identificados(as) com nomes fictícios, escolhidos por eles(as). As convençóes para transcriçăo de fala seguiram as orientaçôes de Magalhăes (2000, p. 15): As barras inclinadas representam interrupçôes na fala; palavras em maiúsculo indicam ênfase na fala da participante; três pontos entre parênteses mostram que uma parte da conversa foi omitida; os colchetes indicam fala simultânea; e, quando alguma parte da fala năo pôde ser entendida, escreve-se: "ininteligível" entre parênteses. Também acrescentei o sublinhado para indicar ênfase minha em algum trecho de interesse na análise.

No tocante às observaçôes, elegi duas disciplinas para acompanhar: uma delas ofertada a alunos(as) da segunda turma do curso e outra ofertada à terceira turma. 
As notas de campo advindas dessas observaçóes foram utilizadas como um meio de acumular informaçóes e conhecimentos e gerar dados que serviram à reflexăo sobre a prática.

Segue uma breve descriçăo dos/das oito participantes da pesquisa neste estudo:

\section{Quadro 1: Perfil de participantes}

\begin{tabular}{|c|c|c|c|}
\hline \multirow{5}{*}{$\begin{array}{l}\text { Participantes } \\
\text { da } 2^{\mathrm{a}} \text { turma }\end{array}$} & Participante & Formação & Profissão \\
\hline & $\begin{array}{c}\text { lara, } \\
39 \text { anos }\end{array}$ & $\begin{array}{c}\text { Letras UFC- } 2012 \\
\text { Especialização } \\
\text { (Ensino de L.P. - UECE -2014) }\end{array}$ & $\begin{array}{l}\text { Profa. há } 6 \text { anos. } \\
\text { Atual: } 200 \text { h/a na rede estadual. }\end{array}$ \\
\hline & $\begin{array}{l}\text { Rosa, } \\
45 \text { anos }\end{array}$ & $\begin{array}{c}\text { Letras UFC - } 1994 \\
\text { Especialização } \\
\text { (Investigação Literária - UFC - 2000) }\end{array}$ & $\begin{array}{c}\text { Profa. há } 23 \text { anos. } \\
\text { Atual: } 100 \text { h/a na rede estadual e } 100 \text { h/a } \\
\text { na rede municipal. }\end{array}$ \\
\hline & $\begin{array}{l}\text { Clarissa, } \\
52 \text { anos }\end{array}$ & Letras UECE - 1985 & $\begin{array}{l}\text { Profa. há } 32 \text { anos. } \\
\text { Atual: } 200 \text { h/a na rede municipal; Profa. } \\
\text { aposentada da rede estadual. }\end{array}$ \\
\hline & $\begin{array}{l}\text { Rânia, } \\
34 \text { anos }\end{array}$ & Letras UFC - 2012 & $\begin{array}{l}\text { Profa. há cerca de } 3 \text { anos. } \\
\text { Atual: } 200 \text { h/a na rede estadual. }\end{array}$ \\
\hline \multirow{4}{*}{$\begin{array}{l}\text { Participantes } \\
\text { da } 3^{a} \text { turma }\end{array}$} & $\begin{array}{l}\text { Rafael, } \\
32 \text { anos }\end{array}$ & Letras UFC - 2007 & $\begin{array}{l}\text { Prof. há cerca de } 9 \text { anos. } \\
\text { Atual: } 200 \text { h/a na rede estadual. }\end{array}$ \\
\hline & $\begin{array}{l}\text { Agnes, } \\
30 \text { anos }\end{array}$ & Letras UFC - 2009 & $\begin{array}{c}\text { Profa. há } 8 \text { anos. } \\
\text { Atual: } 200 \text { h/a na rede estadual. }\end{array}$ \\
\hline & $\begin{array}{l}\text { Laura, } \\
29 \text { anos }\end{array}$ & $\begin{array}{l}\text { Letras UFC - } 2009 \\
\text { Especialização } \\
\text { (Gestão Escolar - 2012) }\end{array}$ & $\begin{array}{l}\text { Profa. há } 7 \text { anos. } \\
\text { Atual: } 200 \text { h/a na rede estadual. }\end{array}$ \\
\hline & $\begin{array}{l}\text { Lia, } \\
37 \text { anos }\end{array}$ & $\begin{array}{l}\text { Letras UFC - } 2002 \\
\text { Especialização incompleta (UVA) }\end{array}$ & $\begin{array}{l}\text { Profa. há mais de } 10 \text { anos. } \\
\text { Atual: } 200 \text { h/a na rede estadual. }\end{array}$ \\
\hline
\end{tabular}

(LOPES, 2016)

Cabe destacar alguns pontos em relaçâo ao perfil dos participantes. Primeiramente, entre os 8 participantes, há apenas 1 homem, o que se justifica pelo fato de as duas turmas observadas serem compostas majoritariamente por mulheres: a segunda turma é constituída de 12 mulheres e 3 homens e a terceira turma é constituída de 13 mulheres e 2 homens. Nesse aspecto, a unidade observada reflete a realidade das 42 instituiçóes associadas a Rede Nacional do Profletras, todas compostas majoritariamente por um público discente feminino. Segundo Benedito Gomes Bezerra, coordenador do Profletras na Universidade de Pernambuco (UFPE) - Campus Garanhuns, os homens săo sempre exceçóes na maioria das turmas do Programa, e năo poderia deixar de ser assim, tendo em vista a presença preponderante de mulheres no ensino de língua portuguesa na educaçâo básica, foco do mestrado profissional.

3 Declaraçâo do coordenador feita em uma postagem sobre o Profletras publicada no blog da Editora Parábola. Disponível em: < https://www.parabolaeditorial.com.br/blog/entry/profletras.html> Acesso em: 22 out. 2016 
Observamos bastante diversidade no que diz respeito à idade e ao tempo de experiência profissional. Quanto à formaçâo, todos os participantes sâo licenciados em Letras, tendo em vista que essa é uma das exigências do programa. Sete dos oito participantes cursaram a graduaçăo na Universidade Federal do Ceará (UFC) e uma é proveniente da Universidade estadual do Ceará (UECE); todos os demais mestrandos que năo participaram da pesquisa săo provenientes de universidades públicas federais ou estaduais, o que pude constatar durante as observaçóes de campo. Nesse aspecto há divergência com a realidade relatada na unidade da UFPE, a qual apresenta mestrandas formadas, em sua maioria, em faculdades particulares. Alguns participantes deram continuidade aos estudos em cursos de especializaçăo, outros năo apresentaram qualificaçăo além do curso de graduaçăo. Um ponto de destaque: a maioria dos(as) participantes relatou um longo período de espera pela oportunidade de cursar um mestrado, alguns deles afastados há mais de uma década do meio acadêmico. Outro destaque é para o regime de trabalho da maioria: $200 \mathrm{~h}$ mensais (40 horas semanais) em atuaçăo na escola, o que evidencia a dificuldade relatada da falta de tempo para dedicação aos estudos.

Os dados advindos das entrevistas com esses participantes foram analisados com base no aporte teórico da Teoria Social do Letramento (STREET, 1984; 2003; 2010; 2012; 2014) e da Análise de Discurso Crítica (FAIRCLOUGH, 2001;2003), tendo em vista que algumas pesquisas anteriores adotaram essa abordagem teórica integradora e já demonstraram a compatibilidade entre as duas teorias (MAGALHÂES, 1995; RIOS, 2009; SATO, 2013; BATISTA JR, 2013, FONTENELE, 2014). Em relaçăo à Teoria Social do Letramento, o intuito é descrever os eventos de letramento do Mestrado Profissional e relacioná-los às práticas de letramento, que por sua vez envolvem dimensóes sociais e culturais, como valores, atitudes, sentimentos e relaçôes sociais. Em relaçăo à Análise de Discurso Crítica, analisa-se o significado identificacional, por meio das categorias modalidade e avaliaçăo, ambas relacionadas ao comprometimento do autor com suas proposiçôes.

Primeiramente, o conceito de evento de letramento é caracterizado por Heath (1983) como qualquer ocasiăo em que algo escrito é constitutivo da interaçâo e dos processos interpretativos dos participantes. Esse conceito relaciona-se aos elementos mais observáveis das atividades que envolvem a leitura e a escrita, ou seja, é o que podemos observar que as pessoas estăo fazendo quando estăo usando a escrita e a leitura. Através dos eventos de letramento o pesquisador ou pesquisadora pode caracterizar quando, onde e como as pessoas leem, escrevem, conversam sobre um texto escrito ou utilizam a escrita para interagir. Os eventos de letramento ocorrem em diferentes espaços sociais, assumem diferentes formas e têm diferentes funçôes. Săo exemplos de eventos de letramento: pegar o ônibus, folhear uma revista, participar de rituais religiosos, ler para o filho, escrever e-mail, conversar sobre um livro na aula, fazer lista de compras. Enfim, em uma sociedade letrada como a nossa, a escrita integra cada momento de nosso cotidiano.

Considero a aula do Profletras como um evento de letramento pelo fato de seus participantes interagirem por meio de textos escritos e seus processos interpretativos estarem relacionados a esses textos. Além disso, a aula apresenta as seguintes características: evento năo homogêneo, com princípio e fim bem definidos, participantes pré-determinados, situado espaço-temporalmente. (Heath, 1983). Segundo Barton (2009), os eventos sáo aninhados uns dentro dos outros com micro e macro eventos. Nessa direçáo, compreendo a aula do Profletras como um macro evento 
de letramento, por tomar a escrita como um eixo estruturador das interaçóes ali vivenciadas. Nesse macro evento realiza-se um conjunto de atividades mediadas pelo texto escrito, que podemos chamar de micro eventos: debate de artigos, apresentaçâo de power point pelos alunos, orientaçóes sobre a produçăo de determinado gênero, entre outros. Barton (2009) diz ainda que os eventos săo encadeados em sequências e estăo em rede através dos contextos. Nesse sentido, é possível perceber que os eventos de letramento do Profletras estăo conectados em rede com os eventos de letramento ocorridos nas salas de aula de educaçấo básica. O acesso a novas práticas de leitura, escrita e discussóes de textos no programa de mestrado profissional, onde estáo posicionados como alunos(as), pode levar a mudanças nas suas práticas de letramento em salas de aula da educaçăo básica, onde atuam como docentes, o que é atestado pela análise das entrevistas.

Podemos aprofundar o exame dos significados atribuídos a esses eventos, alçando-os à categoria de práticas de letramento. Street criou, em 1984, em sua obra clássica, ${ }^{4}$ a expressăo "práticas de letramento", um conceito que possibilita ampliar a análise e a interpretaçấo das práticas sociais que envolvem a escrita. De acordo com Street (2012), as práticas de letramento, ao contrário dos eventos, năo săo diretamente observáveis, portanto, temos que conversar com as pessoas, ouvi-las e ligar os eventos de letramentos dos quais elas participam a outras coisas que elas também façam. Só assim é possível perceber os significados construídos naquele contexto. Magalhăes (2012, p. 26) corroborando essa ideia, afirma: "para serem investigadas de forma adequada, as práticas de letramento demandam a metodologia de pesquisa etnográfica, que estabelece uma relaçáo de convivência com o grupo pesquisado durante um determinado tempo, possibilitando o registro dos processos sociais do letramento: valores, atitudes, sentimentos e relaçóes sociais". É essa relaçăo que me proponho a fazer, observando os eventos de letramento (nas aulas do Profletras) e relacionando-os com aquilo que as participantes relatam, os valores e sentimentos expressos em suas falas (nas entrevistas).

Sâo as práticas de letramento que dâo significado aos eventos, pois "referem-se a essa concepçăo cultural mais ampla de modos particulares de pensar sobre a leitura e a escrita e de realizá-las em contextos culturais" (Street, 2012, p. 77). Nesse modelo de análise, distanciamo-nos do contexto imediato em que os eventos ocorrem para situá-los e interpretá-los em contextos institucionais e culturais e também confrontá-los com as relaçôes de poder. Assim, tentamos responder: Que concepçôes e valores associam-se à leitura e à escrita?

Dentro do enquadre teórico metodológico da Análise de Discurso Crítica, voltome, nesse trabalho, para o significado identificacional, empregando, principalmente as categorias modalidade e avaliaçâo. Dialogando com a Linguística SistêmicoFuncional (LSF), Fairclough (2003) compreende a modalidade como uma categoria ligada a "comprometimentos", "atitudes", "julgamentos", "posturas" e, portanto, ligada à identificaçâo. Ao fazer uso da linguagem, por meio de afirmaçóes, perguntas, demandas ou ofertas, as pessoas escolhem diferentes formas e níveis de comprometimento. Desse modo, a modalidade "é importante na tessitura das identidades tanto

STREET, B. Literacy in theory and practice. Cambridge: CUP, 1984. 
pessoal ('personalidades') quanto social, no sentido de que aquilo com o que a pessoa se compromete é parte significativa do que ela é" (FAIRCLOUGH, 2003, p. 166).5

A modalidade pode ser associada a tipos de troca (de conhecimento e de atividade) e a funçóes de fala (declaraçóes e perguntas; demandas - ordem/pedido e ofertas). 0 foco no primeiro tipo de troca é na troca de informaçăo, na elucidaçăo de afirmaçôes, nas reivindicaçôes, na afirmaçăo de fatos. Já no segundo tipo, o foco é na atividade, nas pessoas fazendo coisas ou conseguindo que as/os outras/as as façam. Frequentemente esta última é orientada para a açăo náo textual. (FAIRCLOUGH, 2003). Afirmaçôes e perguntas referem-se à troca de conhecimento; demandas e ofertas referem-se à troca de atividade. Em trocas de conhecimento, a modalidade é epistêmica, refere-se ao comprometimento com a "verdade"; já na troca de atividade, a modalidade é deôntica, relativa ao comprometimento com a obrigatoriedade/necessidade. O quadro a seguir é elucidativo, ao exemplificar cada uma dessas subcategorizaçôes:

\section{Quadro 2: Tipos de Modalidade}

\begin{tabular}{c|c}
$\begin{array}{c}\text { Modalidade Epistêmica: } \\
\begin{array}{c}\text { Diz respeito às trocas de conhecimento. Pode ser nas } \\
\text { formas de declarações e perguntas. }\end{array}\end{array}$ & $\begin{array}{c}\text { Modalidade Deôntica: } \\
\text { Diz respeito às trocas de atividade. Pode ser nas } \\
\text { formas de obrigações (necessidades) e ofertas. }\end{array}$ \\
\hline $\begin{array}{c}\text { Declarações: refere-se ao grau de comprometimento do } \\
\text { autor ou autora com a verdade e podem ser: }\end{array}$ & $\begin{array}{c}\text { Obrigações (Necessidades): referem-se ao grau de } \\
\text { comprometimento do autor ou autora com obrigação ou } \\
\text { necessidade e podem ser: }\end{array}$ \\
\hline $\begin{array}{c}\text { - Afirmações: A lei está clara. } \\
\text { - Prirmações Modalizadas: A lei talvez esteja clara. } \\
\text { - Negativas: A lei não está clara. }\end{array}$ & $\begin{array}{c}\text { - Modalizadas: Você deveria seguir a lei. } \\
\text { - Proibitivo: Não siga a lei! }\end{array}$ \\
\hline $\begin{array}{c}\text { Perguntas: o autor ou autora explicita o } \\
\text { comprometimento de outrem com a verdade. } \\
\text { Podem ser: }\end{array}$ & $\begin{array}{c}\text { Ofertas: expressam o comprometimento do autor ou } \\
\text { autora em agir. Podem ser: }\end{array}$ \\
\hline $\begin{array}{c}\text { - Positiva não Modalizada: A lei já é oficial? } \\
\text { - Modalizada: A lei poderia já ser oficial? }\end{array}$ & $\begin{array}{c}\text { - Aceitar: Eu seguirei a lei. } \\
\text { - Negativa não Modalizada: A lei já não é oficial? }\end{array}$ \\
\hline
\end{tabular}

Fonte: Fontenele (2014, p. 137)

É possível ainda fazer a distinçăo entre modalidade objetiva e modalidade subjetiva. Na modalidade objetiva, perspectivas parciais podem ser universalizadas, pois a base subjetiva do julgamento está implícita: năo fica claro qual o ponto de vista privilegiado na representaçăo, se "o falante projeta o seu ponto de vista como universal ou age como veículo para o ponto de vista de outro indivíduo ou grupo" (FAIRCLOUGH, 2001, p. 200) (A Terra pode ser/é provavelmente plana). Na modalidade subjetiva, a base subjetiva para o grau de afinidade é explicitada, deixando claro que a afinidade expressa é do(a) próprio(a) falante (Penso/suspeito/duvido que a Terra seja plana).

No que diz respeito à realizaçăo linguística, os marcadores arquetípicos da modalidade na gramática tradicional sâo o "verbos modais" (poder, dever), mas

Traduçâo minha. No original:Modality isimportantinthetexturing of identities, both personal('personalities') and social, in the sense that what you commit yourself to is a significant part of what you are. 
existem muitas outras formas de manifestaçăo: modo e tempo verbal (presente do indicativo manifesta modalidade categórica); advérbios modais ("provavelmente", "possivelmente", "obviamente"); adjetivos equivalentes (é provável/possível); Além dessas, há uma gama um tanto difusa de formas de manifestaçâo de vários graus de afinidade: indeterminaçăo, padrôes de entonaçăo e aspectos da pronúncia, relato em discurso indireto. O quadro a seguir ilustra essa variedade de marcadores de modalizaçăo:

\section{Quadro 3: Marcadores Linguísticos da Modalidade}

\begin{tabular}{c|c}
\hline Marcadores Linguísticos & Exemplos \\
\hline Verbos modais (poder, ter permissão para, dever). & A gente não tinha permissão para sair. \\
\hline Advérbios modais (certamente, possivelmente) & Eu possivelmente farei outra faculdade \\
\hline Advérbios de frequência (frequentemente, sempre, nunca). & Eu sempre gostei de inglês. \\
\hline $\begin{array}{c}\text { Comentários que destacam processos mentais (cativar, atrair, achar, } \\
\text { pensar). }\end{array}$ & O inglês me cativa. \\
\hline Particípio com função de adjetivos (requerido, exigido, obrigado). & A disciplina era exigida na escola. \\
\hline Adjetivos modais (possível, provável, certo) & É certo que eu quero estudar inglês. \\
\hline um tanto. Eu não sei se.., etc) & Eu sou meio quieto. \\
\hline Discurso indireto (atribuição de um comentário a outra pessoa) & $\begin{array}{c}\text { Disseram-me que na universidade } \\
\text { tudo seria diferente. }\end{array}$ \\
\hline Entonação e aspectos da pronúncia (tom hesitante, confiante, agressivo) & \\
\hline
\end{tabular}

Fonte: Adaptado de Ticks (2005, p. 5)

Destacamos a importância do estudo da modalidade nâo apenas para o significado identificacional, pois há mais do que o comprometimento do falante com suas proposiçôes, ela pode também estar ligada a relaçôes sociais, expressando, por exemplo, solidariedade com a pessoa com quem se fala. Hodge e Kress (1988) ressaltam que a afinidade que um (a) produtor (a) demonstra em relaçăo a uma representaçăo de mundo é inseparável do relacionamento (e 'afinidade') entre o (a) produtor (a) e outros(as) participantes do discurso.

As avaliaçôes emitidas pelo(a) produtor(a) de um texto sobre a realidade e os acontecimentos que o(a) cercam também sâo importantes no estudo das identidades, porque revelam a atitude e o posicionamento adquiridos em relaçăo a seus interlocutores. Para dar conta dessa categoria relevante à identificaçăo, tomaremos por base os estudos de Fairlough (2003), o qual, por sua vez, considera as teorias de Graham (2002), Hunston e Thompson (2000) Lemke (1998) e, principalmente, a de Martin (2000) e White (2001). De acordo com Martin e White (2005), o Sistema de Avaliatividade é composto pelos campos semânticos do Engajamento, da Gradaçăo e da Atitude, este último distribuído nos subcampos: Afeto, Julgamento e Apreciaçăo, cada um desses subcampos conta com diversas subcategorizaçōes. ${ }^{6} \mathrm{~A}$ abordagem da avaliaçấo de

$6 \quad$ Sobre a Teoria da Avaliatividade, conferir MARTIN, J.R. \& WHITE, P.R.R The Language of Evaluation: appraisal in English, London: Palgrave MacMillan (2005). 
Fairclough (2003) se distingue por năo fazer detalhadas categorizaçóes para os tipos de avaliaçăo e mostra-se mais viável para os limites do trabalho aqui proposto.

Fairclough (2003) propóe a categoria da Avaliaçâo no estudo do significado identificacional para referir-se a maneiras explícitas ou implícitas com que os(as) autores(as) se comprometem com valores. O referido autor propôe três categorias que podem indicar a materializaçăo das avaliaçóes em aspectos textuais, a saber: afirmaçóes avaliativas, afirmaçóes com modalidades deônticas ou avaliaçōes afetivas e presunçóes valorativas. Em afirmaçóes avaliativas, o elemento avaliativo pode ser mais ou menos explícito. As valoraçóes explícitas podem ser consideradas mais simples, pois podem ser ativadas através de termos que carregam significado negativo ou positivo, como os atributos "bom", "ruim", os verbos "desejar", "rejeitar", os advérbios "felizmente", "infelizmente" ou um sinal de exclamaçăo. A valoraçăo pode ainda ser menos explícita, isto é, inserida em frases e năo afirmada.

Em relaçăo à segunda categoria, Afirmaçôes com modalidade deôntica, é importante destacar que a modalidade deôntica (conforme formulaçăo de Halliday, 1985) pode realizar-se com léxico de natureza claramente valorativa. Fairclough (2013) entende que sentenças com modalidade deôntica (as de caráter de obrigaçăo) săo relacionadas à avaliaçáo e cita o seguinte exemplo: quando Tony Blair diz que "os valores em que acreditamos devem refletir nas nossas açōes no Afeganistăo", 7 a afirmaçăo dele implica, em termos mais gerais, que agir com base em valores é desejável, é algo bom a ser feito.

As Avaliaçóes afetivas sâo mais um tipo de avaliaçăo explícita que envolvem eventos psicológicos, como reflexōes, sentimentos e percepçōes (HALLIDAY, 1985, p. 106). Na concepçâo de Fairclough (2003), essa categoria compreende tanto a utilizaçâo de processos mentais afetivos como processos relacionais. Para ele, a realizaçâo mais comum é por meio de processos mentais afetivos - "Este livro me fascina", mas pode se apresentar como processos relacionais, em que o atributo é afetivo - "Este livro é fascinante". Nesse ponto é interessante notar que, enquanto Fairclough (2003) inclui essas duas relaçôes em uma única categoria que nomeia de Avaliaçōes afetivas, White (2004) reconhece a distinçâo entre construir as emoçóes de um sujeito humano e atribuir às coisas o poder de gerar essas emoçôes, agrupando cada uma dessas realizaçóes em um subsistema - Afeto e Apreciaçâo. Assim, esse autor defende que dizer "Eu gosto daquele quadro" ancora a avaliaçaáo nas reaçōes momentâneas e individuais do falante, enquanto dizer "Aquele é um belo quadro" ancora a avaliaçăo nas propriedades "objetivas" do fenômeno avaliado em si.

Finalmente, as Presunçôes valorativas correspondem ao tipo de avaliaçăo mais implícito, sem marcadores transparentes. Resende e Ramalho (2011) exemplificam com o termo "solidariedade" que constitui um elemento avaliador implícito, com conotaçấo positiva latente. Faiclough (2003) cita o verbo "ajudar", o qual, seja qual for a expressấo colocada a seguir, configura uma avaliaçăo positiva. Porém esses exemplos estâo num nível baixo de complexidade, as avaliaçôes podem ser facilmente percebidas, pois essas expressōes têm significado eminentemente positivo e desejável. Há, no entanto, outros casos em que os valores se encontram em uma esfera muito mais

Traduçăo minha. No original: "The values we believe in should shine through what we do in Afghanistan" (FAIRCLOUGH, 2003, p. 176). 
profunda no texto e dependem da pressuposiçăo de uma familiaridade com sistemas de valores implícitos compartilhados entre autor e receptor. A respeito disso, White (2004) argumenta que as valoraçōes 'implícitas' “levantam sérios problemas teóricos e analíticos [...] passamos de significados vistos como inscritos no texto para significados vistos como operando apenas no contexto". (p. 181). O quadro seguinte apresenta as categorias de avaliaçăo explícita e implícita que acabo de discutir:

\section{Quadro 4: Categorias da Avaliação}

\begin{tabular}{|c|c|}
\hline \multicolumn{2}{|c|}{ Afirmações avaliativas } \\
\hline Categorização & Exemplo \\
\hline Adjetivos Avaliativos & Este é um bom livro. \\
\hline Verbos Avaliativos & Ele se acovardou. \\
\hline Advérbios avaliativos & Ele escreve maravilhosamente. \\
\hline Exclamações & Que livro maravilhoso! \\
\hline Sintagma Nominal (inserido em frases e não afirmado) & Este livro horrivel custa uma fortuna. \\
\hline \multicolumn{2}{|c|}{ Declarações com modalidade deôntica ou Processos mentais avaliativos } \\
\hline $\begin{array}{c}\text { Sentenças com modalidade deôntica (obrigação) } \\
\text { indicam algo desejável. }\end{array}$ & $\begin{array}{l}\text { O professor deve mostrar o valor do seu } \\
\text { trabalho. }\end{array}$ \\
\hline $\begin{array}{l}\text { Avaliações afetivas com a utilização de processos } \\
\text { mentais afetivos ou processos relacionais. }\end{array}$ & $\begin{array}{l}\text { Este método me fascina. } \\
\text { Este método é fascinante. }\end{array}$ \\
\hline \multicolumn{2}{|c|}{ Pressuposições de valor } \\
\hline $\begin{array}{c}\text { Valores implícitos ou pressupostos, indicados por } \\
\text { verbos como 'ajudar'. }\end{array}$ & $\begin{array}{l}\text { As universidades ajudam as pessoas na construção do } \\
\text { seu conhecimento. }\end{array}$ \\
\hline
\end{tabular}

Fonte: Adaptado de Ticks (2005)

Para resumir sua abordagem, Faiclough (2003) sugere algumas perguntas que podem nortear o trabalho do(a) analista quando ele(a) lança mâo da categoria avaliaçâo em um estudo: Com que valores (em termos do que é desejável ou indesejável) o/a autor/a se compromete?; como os valores sâo realizados - como afirmaçôes avaliativas, afirmaçōes com modalidades deônticas, afirmaçōes com processos mentais afetivos ou presunçōes valorativas?

Passo agora a uma descriçăo das práticas de leitura e escrita no Profletras. As notas de campo e as entrevistas foram examinadas para que identificássemos o que, quando, para que e com que propósitos os(as) alunos(as) escreveram/leram no período de um semestre letivo.

\section{DESCRIÇÃO DAS PRÁTICAS ACADÊMICO-CIENTÍFICAS OBSERVADAS NO PROFLETRAS}

Em relaçâo à disciplina ofertada à segunda turma, os(as) alunos(as) produziram, no período de um semestre letivo, textos dos seguintes gêneros discursivos: autobiografia, oficina didática e resenha. Além desses gêneros, também foi proposta uma atividade 
de retextualizaçăo ${ }^{8}$ da crônica "A velha contrabandista", em que o(a) aluno(a) poderia escolher entre os gêneros notícia, relatório, carta ou relato. E ainda: uma prova escrita com questôes sobre os Parâmetros Curriculares Nacionais (PCN). Ao se examinar em que condiçóes tais textos foram produzidos, observei que, em relaçâo à autobiografia, a produçăo desse gênero foi proposta a partir da seguinte pergunta "Quem é você no Profletras?". Essa atividade escrita deveria ser apresentada oralmente, com o propósito de promover uma socializaçăo entre a turma. No entanto, ela foi apenas entregue para a leitura e avaliaçăo da professora, o que acabou conferindo-lhe um caráter artificial e escolarizado.

Na proposta de produçáo do gênero oficina didática, foi sugerido que cada mestrando(a) elaborasse uma sequência didática envolvendo a produçăo escrita de algum texto, focalizando um gênero discursivo específico. Sua funçâo seria a produçấo de um livro eletrônico para ser disponibilizado para outros professores e professoras de Língua Portuguesa, a fim de divulgar atividades de produçâo textual que seguem uma abordagem processual. Antes da publicaçăo, as oficinas foram apresentada à turma, através de seminário, ocasiăo em que a professora tecia consideraçōes e os(as) demais alunos(as) também davam contribuiçôes, ao mesmo tempo que enriqueciam a própria prática com a proposta trazida pelo(a) colega, em uma estratégia de troca, de partilha e de debate dos(as) produtores e dos ouvintes. Para fundamentar a elaboraçâo da oficina didática, os(as) cursistas deveriam ler e resenhar uma obra anteriormente sugerida pela professora da disciplina. A lista era composta de cinco títulos publicados há mais de 10 anos, o que tornava a produçăo a ser feita pelos alunos esvaziada da funçăo social comumente associada a esse gênero, que é de informar, examinar, discutir e apresentar uma avaliaçăo a respeito de uma nova obra, recém-lançada. Apesar disso, constituem, na visăo da professora, obras de leitura obrigatória para professores(as) em formaçăo, todas voltadas para o trabalho com a produçáo de textos na escola. Penso que a resenha, nesse contexto, distanciou-se de sua funçấo mais usual e adquiriu um novo sentido, qual seja: sistematizar a leitura de uma obra que fundamentaria teoricamente a oficina didática.

Em relaçăo à disciplina ofertada à terceira turma do programa, as atividades de escrita solicitadas foram as seguintes: resenha, prova escrita e trabalho final (em forma de artigo ou relato de experiência). A resenha foi proposta de modo a atender a uma de suas funçóes sociais, tendo em vista que a professora propóe que os(as) alunos(as) resenhem uma obra na íntegra, publicada nos três últimos anos, podendo submeter o texto produzido a um periódico para publicaçâo. Dessa forma, podemos dizer que a atividade foi além do contexto institucional e avaliativo em que os(as) participantes se encontravam. Já a prova escrita é um gênero discursivo comumente utilizado somente como instrumento de avaliaçâo da aprendizagem dos(as) alunos(as) e, finalmente, o trabalho final (artigo ou relato de experiência) deveria ser produzido pelos(as) cursistas, tomando por base uma intervençấo em suas salas de aula, fundamentada em teorias estudadas na disciplina. Destaco, portanto, a contribuiçăo da atividade năo somente na apropriaçăo ou retomada da escrita desses gêneros, mas na

8 De acordo com Matencio (2002), a retextualizaçăo é a produçáo de um texto a partir de um ou mais gênero distinto do gênero do(s) texto(s)-base. 
atençăo ao ensino que a atravessa, tornando-a mais significativa para os professores e professoras em formaçăo.

A fim de ilustrar a relaçâo entre a inserçăo nas práticas acadêmico-científicas descritas aqui e os processos discursivos de construçăo de identidade(s), apresenta-se a seçâo seguinte.

\section{AS PRÁTICAS DE LETRAMENTO E AS IDENTIDADES DOCENTES}

A análise indicou que a incursâo em práticas de letramento propiciadas pelo Mestrado Profissional é alavancadora de mudanças discursivas por parte dos(as) cursistas, que, posteriormente, conduzem a mudanças mais profundas, no domínio da açâo. Mapeei essas mudanças em três tipos: aprimoramento da formaçăo prática; incursăo em práticas de letramento específicas do contexto acadêmico; mudanças nas concepçōes sobre o ensino da leitura e da escrita.

Inicialmente, é preciso comentar um descontentamento manifestado por muitos(as) mestrandos(as) em relaçấo à falta de atençáo à prática docente no curso de licenciatura em Letras. Uma das perguntas feitas na entrevista foi a seguinte: "Como você avalia a formaçáo inicial em relaçăo aos saberes necessários para o exercício da profissăo? ". Algumas de suas respostas foram significativas porque acabaram por revelar o distanciamento entre os saberes acadêmicos e a prática de sala de aula.

A fala das participantes Iara, Rânia e Agnes indica essa insatisfaçăo:

Iara: A gente estuda todas as teorias, mas a gente năo vê uma aplicabilidade no final, né? Faz muita falta isso, principalmente porque aqui é um curso de licenciatura, aí a gente só vai ver lá no final quando os conteúdos já năo estăo tăo mais frescos, né?

Rânia: A graduaçăo tem muita coisa, como eu falei, vou ser bem sincera agora năo se aproveita, assim, pra vida real, né, que era só uma disciplina que você tinha que cursar porque você, tava lá na grade do curso, do programa, mas que ela vá servir, náo.

Agnes: $\mathrm{O}$ que a gente aprende na universidade na graduaçáo está muito aquém do que a realidade exige. [...] Em relaçăo ao que a gente vê na graduaçáo de Letras pra prática é muito pouco, né? A gente tem poucas disciplinas em relaçăo a isso as disciplinas de, de, estágio săo muito poucas, săo pouco acompanhadas, né?

Identificamos, nos trechos, o uso de declaraçōes (modalidade epistêmica), que exploram fatos (realis statements). Por meio de declaraçóes afirmativas e negativas, apresentam informaçōes categóricas (presente do indicativo), com um grau maior de assertividade: "está muito aquém", "é muito pouco", "nâo se aproveita", "năo vê uma aplicabilidade". Esses excertos constituem também declaraçôes de valor, que sâo avaliaçōes negativas, pois se entende que o ensino náo era muito utilitário. Fica pressuposto que o ensino deve ter uma utilidade de caráter prático, que, no caso dos cursos de licenciatura, consiste na preparaçăo para a atuaçăo docente. A formaçăo prática, segundo as participantes, ocorre somente no final do curso e é limitada às disciplinas de estágio, que săo "muito poucas" e "pouco acompanhadas".

Outro destaque é para o uso da locuçâo pronominal inclusiva "a gente". Fairclough (2003) alerta-nos que, para além das marcas modalizadoras, outras categorias, como os pronomes pessoais, também contribuem para a construçăo da identificaçáo dos 
participantes. O poder de fazer declaraçóes em nome de outras pessoas (a gente), como representante da classe, mostra que as participantes veem a si mesmas como conhecedoras dos problemas e capazes de comprometer-se fortemente com aquilo que afirmam nâo só em relaçấo a elas, mas em relaçăo a todos os professores e professoras formados(as) no curso de Letras.

Considerando-se a modalidade deôntica, existe uma só ocorrência explícita: "você tinha que cursar", denotando o caráter de obrigatoriedade da disciplina. Podemos relacionar a modalidade deôntica à avaliaçấo, com base em Fairclough (2003). Segundo o autor, no caso das obrigaçóes, as avaliaçóes aparecem como se as açóes do sujeito devessem ser motivadas por determinados valores desejáveis e náo por outros. No trecho em questăo, temos uma avaliaçăo negativa, pois fica claro que a disciplina náo terá uma utilidade prática, mas que é cursada apenas pela necessidade de cumprir a grade curricular do curso. Verifica-se outra ocorrência que remete ao comprometimento com uma necessidade, mas de forma implícita: "A gente estuda todas as teorias, mas a gente nâo vê uma aplicabilidade no final, né? Faz muita falta isso, principalmente porque aqui é um curso de licenciatura". Quando se diz isso, supóe-se que um curso de licenciatura, mais que os outros, deva relacionar teoria e prática, sob o risco de ser incompleto, caso náo o faça. Nesse caso podemos perceber também uma marca de avaliaçăo da informante, expressando o que é desejável em um curso de licenciatura.

$\mathrm{O}(\mathrm{A})$ professor(a) formado(a) no curso de licenciatura em Letras depara com os limites de dominar apenas o conhecimento sobre o funcionamento da linguagem para dar conta das dificuldades de aprendizagem dos(as) alunos(as). Perceberá logo a necessidade de conjugar esses conhecimentos com outros saberes, para entăo multiplicar as suas possibilidades de criar situaçôes significativas de aprendizagem. É nesse contexto que o Mestrado Profissional surge como uma oportunidade de refinar esses conhecimentos e aprimorar a formaçăo prática. Podemos ver uma avaliaçăo positiva do curso quanto aos saberes necessários para o exercício da profissâo:

Rânia: Diferente do mestrado Profletras que realmente nada é desperdiçado, assim, muito pelo contrário, ele é muito intenso, e, penso que, na graduaçăo você aproveita $60 \%$ do que você estudou e no mestrado você aproveita $90 \%$.

Rosa: eu tenho uma prática, eu sou muito voltada pra prática entăo eu achei bacana eu ir pro Profletras entăo eu acho, eu acho que eu faço assim, eu assimilo as coisas e depois através da minha prática eu vou introduzindo.

Através do uso do adverbio modal "realmente", a participante Rânia manifesta alto grau de afinidade com a afirmaçăo que faz em relaçăo ao aproveitamento do que se estuda no curso para a profissâo docente. E com o uso da expressâo "muito pelo contrário" ela estabelece forte distinçâo entre o Profletras e a graduaçâo. Inicia a narraçâo com uma modalidade objetiva, em que a falante projeta o seu ponto de vista como universal: ("nada é desperdiçado"; "ele é muito intenso"). Já ao utilizar o processo mental "penso", a base subjetiva para o grau de afinidade é explicitada, deixando claro que a afinidade expressa é da própria falante; ela demonstra, assim, uma crença pessoal do aproveitamento dos conhecimentos adquiridos. O segundo excerto também mostra o uso de modalidade subjetiva, com comentário que destaca o processo mental "acho", ao falar da transposiçấo dos conteúdos do Profletras para a sua prática docente. 
Aqui temos afirmaçôes avaliativas explícitas: o primeiro excerto destacado apresenta processo relacional (é) com um atributo (intenso) que expressa percepçáo positiva e é intensificado por advérbio (muito); o segundo excerto apresenta um enunciado avaliativo (eu achei bacana). Ambas enfatizam a importância do Profletras como programa que estabelece maior relaçâo entre a teoria linguística e o ensino-aprendizagem em sala de aula.

Uma procura por essa formaçāo de caráter mais prático é um dos motivos que levou os(as) participantes a ingressarem no Profletras, além da acessibilidade para pessoas que trabalham, possibilidade de ascensăo profissional e salarial, entre outros:

\begin{abstract}
Iara: Entâo, eu tinha acabado de entrar na escola pública, fiquei, conheci e aí resolvi fazer a prova, e aí, assim, gostei da proposta, porque era relacionado ao ensino que era uma coisa que já me interessava, [...] eu achei que fosse talvez, fosse mais leve no sentido de que, como eu náo poderia pedir afastamento, porque eu estava no período probatório, entâo eu achei que o Profletras tivesse uma grade mais adequada pro meu momento, né? [...] a gente aprende a relacionar mais a teoria com a prática náo tanto quanto eu esperava, né, mas talvez, talvez seja uma pretensáo muito grande minha mas pelo menos tem muitos caminhos que foram apontados [...] quando aparece um problema você já sabe mais ou menos que caminho tomar né, entăo, assim, esse primeiro semestre foi muito importante realmente foi um divisor, foi um divisor de águas. [...]
\end{abstract}

Rosa: E aí eu entrei no mercado de trabalho comecei a trabalhar dar um monte de aula, você tem que dar muita aula pra conseguir um salário razoável e você vai perdendo né é.... contato com as coisas que estăo acontecendo contato com leituras e sempre há uma vontade de fazer um mestrado só que é tudo muito/muito distante a realidade, entăo eu acho que eu tentei alguma vez no acadêmico náo deu certo aí eu soube dessa do Profletras eu achei muito interessante e náo vamos mentir todo mundo que tá em sala de aula gostaria de fazer um mestrado pra melhorar o seu salário que acaba năo sendo/ normalmente năo é tăo significativo assim, mas é uma saída, né? Entăo eu fiquei muito contente quando eu soube do Profletras e aí por tá longe do mundo acadêmico você já náo sabe mais como preparar um projeto, você tá muito distante, [...] Entăo, quando surgiu o Profletras foi uma tábua de salvaçăo.

Um destaque nesses trechos é para o uso das metáforas, segundo Fairclough (2001), quando significamos algo por meio de uma metáfora e náo de outra estamos construindo nossa realidade de uma maneira e náo de outra, o que sugere filiaçâo a uma maneira particular de representar aspectos do mundo e de identificá-los. No primeiro relato transcrito, a participante Iara avalia o primeiro semestre da formaçăo como "muito importante", o que constitui uma atitude de julgamento, em termos da relevância do programa curricular do Profletras. Com o uso da metáfora do "divisor de águas", evidencia-se essa importância, ao qualificar o programa como um marco que trouxe transformaçóes profundas, supostamente positivas e que vai definir sua prática docente em antes e depois. No segundo relato, a participante Rosa utiliza a metáfora da "tábua de salvaçâo", caracterizando o programa como último recurso para atingir uma ascensâo profissional e uma continuidade dos estudos acadêmicos, tendo em vista que a formaçâo "é uma saída" para "melhorar o seu salário" e constitui-se também como uma oportunidade de voltar à academia, uma vez que o mestrado acadêmico "é muito distante". 
Podemos verificar também essa motivaçâo para a procura do curso pela análise das notas de campo:

A professora deu início à aula com o questionamento dos motivos pelos quais haviam escolhido o Profletras. Um(a) aluno(a) relatou que, afastado(a) da vida acadêmica, - Profletras foi uma oportunidade para buscar novos conhecimentos para a sala de aula, bem como novos métodos bem fundamentados e preparar-se melhor para responder as dúvidas dos alunos. Outro/a demonstrou a "vontade sempre de fazer um mestrado", mas por estar distante do meio acadêmico sentiu insegurança para tentar o Mestrado Acadêmico. Outro/a ainda relatou que a proposta do Mestrado Profissional casaria melhor com seus objetivos, por estar voltado para o trabalho em sala de aula. Um(a) aluno(a) coloca como motivaçăo a "busca de soluçóes para os problemas da sala de aula", ao que outro(a) rebate: "Nâo sei se vou encontrar soluçôes ou mais problemas" Alguns/algumas citaram a necessidade de superar a funçăo de professor "dador" de aula, aquele limitado e reprodutor do livro didático. (Nota de campo-18/03/2016)

Como se vê, um dos motivos para a escolha do Profletras foi a proposta do programa de manter um vínculo mais estreito com a profissăo e voltar-se para as necessidades e situaçōes vivenciadas na prática docente, com o objetivo de ajudar professores(as) a solucionar as situaçóes problemáticas com as quais podem deparar. Além de aperfeiçoar a prática docente, os(as) mestrandos(as) também se apropriam de novos gêneros discursivos acadêmico-científicos, como o artigo científico e o projeto de pesquisa:

Rafael: Na graduaçăo, primeiro que eu năo tive monografia, né, năo tive trabalho de conclusấo de curso, alguns professores pediam ensaios, eram avaliaçôes escritas mesmo, artigo, resenha, muito aquela coisa focada naquela disciplina [...] era muito seminário, prova escrita, resenha, ensaio, artigo, artigo muito pouco, eu nem me lembro se eu fiz algum artigo, acho que eu fiz, mas mais eram seminário e apresentaçấo de ensaios, ensaios críticos, né?

Agnes: (No Profletras) tem gêneros da graduaçăo como a resenha, mas tem artigo científico que a gente nâo fez na graduaçăo, eu nunca fiz um artigo cientifico na graduaçáo e na verdade vou fazer, vou tentar fazer agora, relato de experiência mesmo eu já produzi um na graduaçăo, e o projeto que é novo pra gente. Na minha graduaçăo eu náo fiz monografia, entăo a gente tá aprendendo do zero a fazer um projeto.

Lia: Até hoje eu năo entendo como que eu terminei o curso de Letras e eu năo fiz o TCC, năo me foi cobrado entăo essa ideia de como criar um projeto năo foi a mim ensinado durante a graduaçấo, e eu no momento eu comemorei porque foi uma cobrança a menos, mas depois eu sofri devido a essa falta na minha grade curricular, no meu desempenho acadêmico.

O participante Rafael aponta ensaio, prova, resenha e seminário como os principais gêneros solicitados na graduaçâo. Ele avalia essa prática de produçâo escrita com a expressấo "muito aquela coisa focada naquela disciplina", deixa claro, portanto, que essas atividades năo tinham uma funçâo social própria, eram realizadas apenas para atestar os conhecimentos adquiridos na disciplina. Através do advérbio de frequência ("nunca") a participante Agnes desvela a ausência total da prática de escrita de artigos científicos na graduaçâo e através das declaraçōes "na verdade vou fazer, vou tentar fazer agora" e "aprendendo do zero" evidencia também a aquisiçăo de uma nova prática de escrita acadêmica: o projeto de pesquisa. 
A respeito da escrita do projeto, a participante Lia revela um momento de sofrimento pela falta dessa prática em sua graduaçâo. O processo de seleçâo diferenciado do Mestrado Profissional, sem a exigência de um anteprojeto de pesquisa é, inclusive, apontado muitas vezes como uma grande motivaçăo para a procura pelo curso. Alguns alunos/alunas năo se sentem preparados(as) para produzir esse gênero, uma vez que nâo tiveram esse aprendizado durante a graduaçăo.

Em relaçăo ao projeto de pesquisa, os(as) alunos(as) cursam uma disciplina específica para a produçāo desse gênero discursivo. $O$ artigo científico é outro gênero discursivo apontado como novo no contexto do Mestrado Profissional e em uma das disciplinas observadas, a professora dedicou um tempo da aula para dar orientaçôes acerca das suas características:

Segundo orientaçăo da professora, o trabalho final da disciplina precisa estar voltado para o trabalho em sala de aula e pode ser feito na forma de um artigo ou relato de experiência. Sobre a estrutura do artigo, escreve na lousa cada parte desse gênero e explica cada uma delas: Na Introduçấo, devem ser apresentadas as questóes e objetivos do trabalho, na Teoria ou Estado da Arte devem ser apresentadas as teorias que fundamentam a pesquisa, mas sem "chover no molhado", na Metodologia devem explicar como foi feito o trabalho, na Análise devem proceder à análise dos dados e devem concluir com uma seçâo de Consideraçôes Finais. Por fim, devem incluir as Referências. A professora destaca ainda que o trabalho deve ter uma circularidade entre teoria e prática. (Nota de campo - 06/05/2016).

Quero destacar, contudo, que um conjunto de regras ou de instruçóes transmitidas pelo(a) professor(a) năo é suficiente para que os(as) alunos(as) passem a dominar a escrita de um gênero discursivo. Além disso, o letramento na academia náo se limita aos gêneros produzidos nesse contexto (tese, dissertaçăo, monografia, artigo, ensaio, resenha, resumo, entre outros), mas está relacionado também a práticas específicas da academia com usos e significados próprios, como a reescrita, o tratamento de temas polêmicos, a discussăo, o desenvolvimento de um espírito crítico, a consideraçăo/atençâo do leitor nos textos produzidos. A apropriaçâo de uma leitura crítica é apontada como uma das grandes contribuiçôes da formaçăo continuada, conforme afirma a cursista Iara: "dessas práticas de letramento talvez o que eu leve mais forte pra sala de aula seja a questăo da discussăo, da oralidade".

Já falei a respeito do que se lê no contexto do Profletras, outra questăo importante a ser debatida é "Para que se lê"? A professora da disciplina ofertada à terceira turma estava tentando introduzir uma forma de leitura crítica, por isso requeria que os(as) alunos(as) demonstrassem a capacidade de relaçâo das leituras e avaliaçāo das obras quanto a inovaçôes e limitaçóes. Os(As) cursistas demonstravam grande dificuldade nos momentos em que eram solicitados(as) a falar para a turma. Uma aluna, ao ser convidada a falar, declara: "eu nâo sei se eu vou conseguir atingir a sua meta". Segundo Marinho (2010), uma das dificuldades que os(as) alunos(as) em contexto acadêmico enfrentam é a de entender que concepçóes e expectativas têm os(as) seus/suas professores(as) quando lhes demandam uma tarefa de leitura ou de escrita.

O relato de uma cursista durante a aula é muito significativo para entendermos que parte dessa dificuldade nas leituras, no contexto do Profletras, está relacionada à falta de tempo para dedicaçăo aos estudos, tendo em vista que os(as) cursistas precisam conciliar as funçōes de professor(a) e mestrando(a): 
Nós também estamos aqui na condiçáo de alunos, se compararmos o mestrado acadêmico com o mestrado profissional, nós năo tiramos licença, trabalhamos, a maioria dos alunos no mestrado acadêmico tira licença. [...] Quando náo conseguimos fazer todas as leituras năo é por falta de interesse e foco, cada classe tem uma realidade e é importante o professor considerar. (Relato de uma aluna durante observaçăo realizada em 27/05/2016).

Vimos até agora que o Mestrado Profissional em Letras promove uma aproximaçăo entre os saberes científicos e a prática docente, o que era feito de modo incipiente na graduaçăo, e dissemina conhecimentos sobre práticas de leitura e de escrita de gêneros discursivos acadêmico científicos. Além disso, é possível perceber uma mudança nas concepçôes de letramento que orientam as práticas docentes dos(as) cursistas. Em uma das observaçôes, uma aluna relata que um dos problemas para o qual ela busca soluçáo no Mestrado Profissional é o fato de encontrar alunos nas séries finais do Ensino Fundamental e já no Ensino Médio com dificuldades básicas, sem atender os pré-requisitos para aquela série. Podemos perceber que o ensino da leitura e da escrita é concebido, nessa situaçăo, como gradaçăo: pré-conhecimento de séries anteriores para avançar para outras. O discurso repetido por professores "Você já deveria saber" leva o aluno a ver-se sempre na falta.

Marinho (2010) fala a respeito desse discurso dominante de déficit para a compreensấo da escrita e do letramento do(a) estudante em contextos formais de ensino. Os(As) professores(as) consideram que há lacunas de um processo de escolarizaçấo supostamente deficitário, de aprender aquilo que deveriam ter aprendido antes. Na maioria das vezes, o(a) docente náo explicita de forma suficiente determinados conteúdos, supondo que o(a) aluno(a) já sabe, por ser objeto de estudo de séries anteriores; sem uma concepçâo clara do conteúdo, os(as) alunos(as) văo aprendendo subliminarmente, por tentativas de acerto e erro, a responder adequadamente às atividades escolares que lhe săo propostas. A respeito disso, Barton (2009), destaca que os discursos contemporâneos sobre a educaçăo muitas vezes recorrem ao discurso limitado de habilidades e ao discurso do déficit e da culpa. Os Estudos de Letramento oferecem um discurso particular, uma maneira de falar sobre o letramento que desafia essa visâo predominante, por ser baseado em uma teoria do letramento como prática social e apresentar a possibilidade de ser desenvolvido em uma prática da pedagogia social.

A respeito da fala da cursista, a professora da disciplina comenta que o que se considera como pré-conhecimento para determinada série tem que ser sempre retomado, nunca pressuposto como conhecimento partilhado; concordo que a pressuposiçáo é frustrante tanto para professor(a) como para aluno(a), pois professores(as) constatam que os alunos náo sabem o que já deveriam saber e alunos(as) acabam por internalizar uma postura auto discriminatória, reconhecendo-se como incapazes de avançar no conhecimento. $O$ modelo ideológico de letramento oferece uma concepçăo alternativo do ensino, visto como algo contínuo, em que, a qualquer momento, os conhecimentos podem ser retomados.

Outra aluna, ao comentar o relato da primeira, justifica que professores(as) reproduzem esse discurso devido a dois fatores: primeiramente, o sistema de ensino é baseado nessa perspectiva de gradaçăo, em que sâo solicitados dos(as) professores(as) planos de aula que devem seguir esse modelo. E ainda: a forma como os(as) professores(as) aprenderam, enquanto alunos(as), é essa. Essa aluna, entâo, aponta dois desafios 
para uma possível mudança: primeiro a imposiçăo do "sistema de ensino", que dita as regras do trabalho do professor; de acordo com Gee (2000 apud FONTENELE, 2014), a profissăo de professor é uma identidade institucional e, portanto, é uma posiçấo atingida. A força que determina essa posiçăo é um grupo de autoridades, tanto governamentais quanto acadêmicas e o processo pelo qual essa força funciona é a autorizaçăo, ou seja, leis, regras, tradiçôes e princípios de vários tipos que permitem às autoridades "criarem" a posiçấo de professor/professora com suas respectivas responsabilidades e direitos.

Além disso, segundo a mestranda, a dificuldade em superar o modelo está ligada a experiência que tiveram com a profissăo ainda enquanto alunos(as), o que faz todo o sentido, porque os(as) futuros(as) professores(as) săo expostos(as) a essa cultura de ensinar e aprender antes de decidirem por frequentar um curso de licenciatura. Na verdade, essa formaçăo começa a ser construída pela observaçăo da prática do ensino ainda no papel de aluno(a) da educaçăo básica: "A constituiçăo do ser professor, isto é, de sua identidade, perpassa diversas questóes que văo desde a sua socializaçăo primária, enquanto aluno da escola, seguindo para a formaçáo inicial em cursos de licenciatura, até tornar-se professor de fato, ficando em formaçăo permanente" (IZA et al, 2014, p. 277).

Em outra aula da mesma turma, pude observar, no relato de outra mestranda, uma mudança nessa concepçăo que parte do modelo de déficit para uma visăo do ensino como um processo contínuo, com idas e vindas. A cursista relatou que fez a leitura de um artigo proposto para uma disciplina, cujo título é "Corrigir ou nâo variantes nâo padrăo na fala do aluno?" (BORTONI-RICARDO e OLIVEIRA, 2013), e depois dessa leitura ela passou a pensar sobre a sua própria prática. Se antes, nas palavras da própria mestranda, ela "sentia ódio" ao ler uma produçăo textual e deparar com vários erros de ortografia, perguntando-se como aquele(a) aluno/aluna teria chegado àquela etapa de ensino cometendo tantos erros, agora ela tomava consciência de que a aprendizagem da escrita é um processo que leva muito tempo, às vezes é um processo da vida toda. Nas palavras das autoras do texto, em um trecho citado pela cursista, a alfabetizaçăo tem momento para começar, mas nâo tem momento para terminar. Esse relato mostra reflexôes que podem ser um indício de uma mudança na prática.

É claro que o enfoque na correçâo ortográfica, citado pela mestranda, é uma prática do Modelo Autônomo de Letramento. Esse modelo em que a escrita é trabalhada de forma abstraída da realidade, descontextualizada e sem sentido para o(a) aluno(a) é naturalizado e internalizado pelos(as) professores(as). Mas através das leituras e debates em sala, professores e professoras tomam consciência das implicaçóes desse modelo e há, entăo, a possibilidade da construçăo de uma nova identidade, com novas possibilidades de atuaçăo.

Porém há que se destacar que essas mudanças fazem parte de um processo, contínuo e demorado, e muitas vezes há dificuldade de abandonar velhas práticas arraigadas do modelo autônomo, é o que constatei nos relatos dos(as) cursistas, durante a observaçâo participante. Alunos e alunas demonstraram que consideram ser necessário o uso do modelo autônomo quando se quer trabalhar questóes de ortografia e gramática. Eles insistem em que é preciso tirar um tempo da aula para dedicar ao modelo autônomo, ao relatar em sala de aula: "o ensino da ortografia, por exemplo, é regra, náo tem como náo ser mecânico". A professora da disciplina contra argumenta que é possível trabalhar com o modelo ideológico com vistas a desenvolver todos os 
aspectos do ensino, conduzindo o trabalho pedagógico de maneira adequada, lúdica, sem a perspectiva redutora de focar somente a gramática, pois, segundo ela, o foco da aula deve ser o acesso ao conhecimento, nâo a correçăo gramatical. Logo, a adoçâo do modelo ideológico significa ligar o trabalho pedagógico à vida social, contribuir para o seu desenvolvimento, explorar a proximidade dos alunos com questóes da comunidade, relacionar o ensino com o próprio contexto dos alunos, enfim, trazer as suas práticas socioculturais para a sala de aula.

No relato a seguir, gravado em sala de aula, uma cursista fala das dificuldades de incorporar o modelo ideológico à sua prática docente:

a nossa experiência em sala de aula também denota, né que nós ainda por muitas vezes por mais que compreendamos, né, o letramento ideológico, a gente, de certa forma, ainda impóe esse letramento autônomo em sala de aula porque, como os textos falam, a gente acredita que/ nós internalizamos que o letramento autônomo ele traz progresso, né, ele traz é ,é melhores é, é possibilidades de, de condiçōes de vida, de acesso e entăo nós temos que mudar, né, as concepçôes de letramento das comunidades para inserir novos tipos de letramento porque assim essa comunidade vai ser melhor, né? [...] sempre durante essas leitura, a gente faz, nós somos pessoas da prática, né, a gente tá em sala de aula o tempo inteiro, entâo todos os textos que eu leio, sempre, né, falando de mim, eu fico é, pensando na minha prática, né? E eu fico, ah eu tô fazendo isso, eu faço isso, eu faço isso, eu faço isso (entre risos) e é péssimo né, porque a gente chega à conclusăo que por mais que (ininteligível) teoricamente a gente saiba que náo é adequado, muitas vezes ali no dia a dia, na prática de sala de aula, tem outros contextos, e eu trabalho com os $6^{\circ}$ né, eles sâo pequenininhos, o principal motivo da indisciplina eu faço alguma coisa que ela diz aqui nesse texto que pra que haja disciplina a gente acaba/ a gente eu, né? Tô falando eu, acaba é, é, realizando práticas que promovam que eles fiquem disciplinados pra escutar aquilo que eu tô dizendo né, e, e, essas práticas elas năo săo adequadas, muitas vezes, muitas vezes elas sâo impostas, muitas vezes elas castram, né, a aprendizagem do aluno, mas eu preciso daquilo ali muitas vezes pra conseguir sobreviver dentro daquele, dentro daquele contexto da sala de aula. (Relato de uma aluna gravado durante observaçấo realizada em 27/05/2016).

Apesar do uso frequente da forma adverbial "né" como pedido de confirmaçăo do enunciado anterior, percebemos, no emprego da modalidade epistêmica, um alto grau de envolvimento da falante, que se posiciona claramente em relaçáo ao que declara, expressando a dificuldade em aplicar na prática o modelo ideológico do letramento. A falante se identifica com o tipo de comportamento que ela descreve, seja na primeira pessoa do plural ("nós internalizamos que o modelo ele traz progresso"), ou do singular ("eu faço alguma coisa"). O comprometimento da falante é modalizado (através da expressâo mitigadora "de certa forma") quando fala da imposiçáo do modelo autônomo pelos professores, mas em outros momentos os advérbios de frequência ("sempre", "muitas vezes") reforçam a reflexăo contínua dos(as) docentes sobre a própria prática e as razôes para a adoçâo de práticas inadequadas em sala de aula.

Ela defende que as dificuldades de aplicaçâo do modelo ideológico do letramento na prática de sala de aula sâo motivadas, em primeiro lugar, pela própria concepçâo do modelo autônomo, internalizada por muitos professores, de que é preciso desenvolver nos alunos as habilidades individuais para que eles sejam aprovados nos exames externos, consigam um bom emprego e alcancem a mobilidade social. Ela também cita o texto discutido em aula "(Des)vantagens de atividades mecânicas e de trabalhos em 
grupos anódinos" (MACHADO, 2013) para embasar o seu argumento de que devido à rotina de sala de aula, muitas vezes, ela precisa aplicar atividades mecânicas e sem sentido para manter a ordem.

Além dessas dificuldades relatadas de ultrapassar concepçōes naturalizadas e ainda de enfrentar problemas estruturais do ensino, como salas de aula superlotadas, indisciplina, violência, falta de recursos, há também outra barreira para a consolidaçâo de práticas de letramento ideológico no ensino: a existência de relaçôes assimétricas de poder. Uma preocupaçáo constantemente relatada pelos(as) cursistas é quanto às mudanças no ensino influenciadas pelos exames externos, principalmente o Enem. É possível perceber que o Estado impóe mudanças e estratégias de controle, que fazem com que os(as) professores(as) vivenciem uma verdadeira tensâo em sua identidade: seguir o modelo arquitetado pela política curricular oficial, com seu modelo escolar burocrático, conteudista e cientificista que a educaçăo pública brasileira vem assumindo por pressâo do mercado de trabalho e cada vez mais distante de seus vínculos culturais e sociais ou construir identidades subversivas, baseando o ensino em uma pedagogia da prática social (BARTON, 2009).

\section{CONSIDERAÇÕES FINAIS}

O Curso de Licenciatura em Letras prioriza os saberes de ordem linguística e pouco aborda os conhecimentos sobre o processo de ensinar/aprender línguas. Tal questăo pouco contribui para a construçáo da identidade do(a) futuro(a) professor(a) de Português. Muitos pesquisadores e pesquisadoras, a exemplo de Tardif (2002), apontam para a necessidade de reorganizaçâo dos programas de formaçăo, de modo que se possa vincular, além da formaçaao geral e científica, uma formaçâo prática. Para efetivar-se essa mudança seriam necessárias açōes como estágios de longa duraçăo, contatos repetidos e frequentes com os ambientes da prática, cursos dedicados à análise das práticas, análise de casos.

Nesse contexto, o Profletras constitui uma modalidade de formaçăo continuada que tem a funçấo de permitir ao(à) professor(a) uma "reciclagem" do conhecimento com o estudo de teorias atualizadas e, sobretudo, provocar situaçóes de reflexâo sobre a prática pedagógica, e viabilizar novas açôes em sua atuaçăo docente, por meio de conhecimentos sobre os métodos e modos de ensinar.

Além da formaçăo prática, os(as) cursistas sâo expostos(as) a práticas de escrita acadêmica que alguns(as) deles(as) nunca vivenciaram no contexto da graduaçáo; entre os gêneros discursivos que produzem pela primeira vez estăo o artigo científico e o projeto de pesquisa. Os(As) participantes denotam, em sua fala, um momento de sofrimento que perpassa esse desenvolvimento educacional. Outra contribuiçāo do curso é a habilidade de avaliar e se posicionar em relaçăo ao conteúdo dos textos lidos. Segundo Marinho (2010), essa prática de leitura crítica demanda "um laborioso trabalho e um tempo de convivência que atravessa todo o curso de graduaçăo, năo tendo um ponto final para aqueles que se aventuram na trajetória acadêmica de mestrado, doutorado e pesquisas" (p. 370).

Outra mudança mapeada diz respeito às concepçōes do ensino de escrita e leitura. Através das leituras e debates em sala, professores e professoras cursistas tomam 
consciência das implicaçóes do modelo autônomo de letramento, internalizado e reproduzido, e há, entăo a possibilidade da construçăo de uma nova identidade, com novas possibilidades de atuaçăo. É claro que, nesse processo de mudança, eles(as) enfrentam muitos desafios, sejam problemas estruturais do ensino, sejam as estratégias de controle do Estado, ou ainda a superaçáo de um modelo engessado e adquirido desde a socializaçăo primária. A esse respeito, Street (2012) argumenta que é preciso avançar além das críticas unicamente teóricas ao modelo autônomo de letramento e desenvolver propostas de aplicaçōes práticas do modelo ideológico. As perspectivas teóricas reunidas nos Novos Estudos do Letramento precisam fazer essa mediaçăo da teoria na prática, o que constitui uma agenda para pesquisas futuras. É necessário que os estudos nesse campo avancem para que o letramento como prática social deixe de ser apenas disseminado em discursos educativos e seja, de fato, incorporado a práticas pedagógicas, principalmente no sistema público de ensino. 


\section{REFERÊNCIAS}

BARTON, D. Understanding textual practices in a changing world. In: BAYNHAM, M; PRINSLOO, M. Basingstoke (eds). The Future of Literacy Studies : Palgrave Macmillan, 2009. p. 38-53.

BATISTA JÚNIOR, J. R. L. Discurso, identidade e letramento no atendimento educacional à pessoa com deficiência. 2013. 310 f., il. Tese (Doutorado em Linguística) Universidade de Brasília, Brasília, 2013.

BORTONI-RICARDO, S. M.; OLIVEIRA, T. de. Corrigir ou náo variantes náo padrăo na fala do aluno? BORTONI-RICARDO, S.; MACHADO, V. R. (orgs). Os doze trabalhos de Hércules: do oral para o escrito. Sáo Paulo: Parábola Editorial, 2013.

FAIRCLOUGH, N. Discurso e Mudança Social. Coord. Trad., revisăo e prefácio à Ed. Brasileira de I. Magalhăes. Brasília, DF: Editora Universidade de Brasília, 2001.

FAIRCLOUGH, N. Analysing Discourse - Textual Analysis for Social Research. London: Routledge, 2003.

. A dialética do discurso. In: MAGALHÂES, I. (org.). Discursos e práticas de letramento. Campinas, SP: Mercado de Letras, 2012.

FONTENELE, L. M. S. O novo contexto da educaçăo especial: uma pesquisa etnográficodiscursiva sobre identidades profissionais e maternas. 2014. $251 \mathrm{f}$. Tese (Doutorado em Linguística) - Universidade Federal do Ceará, Fortaleza, 2014.

HALLIDAY, M.A.K. Introduction to Functional Grammar, London: Edward Arnold, 1985. HEATH, S. B. Ways with words. Cambridge: Cambridge University Press, 1983.

HODGE, Robert; GUNTHER Kress. Social Semiotics. London: Polity Press, 1988.

IZA, D. et al, Identidade docente: As várias faces da constituiçăo do ser professor. Revista Eletrônica de Educaçăo, v. 8, n. 2, pp. 273-292, 2014.

MACHADO, V. R. (Des)vantagens de atividades mecânicas e de trabalhos em grupo anódinos. In: BORTONI-RICARDO \& MACHADO, V. R. (orgs). Os doze trabalhos de Hércules: do oral para o escrito. Săo Paulo: Parábola Editorial, 2013.

MAGALHĂES, I. Práticas discursivas de letramento. A construçăo da identidade em relatos de mulheres. In: KLEIMAN, A. B. (org.). Os significados do letramento. Campinas, SP, Mercado de Letras, 1995. p. 71- 96.

. Eu e Tu: a constituiçăo do sujeito no discurso médico. Brasília: Thesaurus, 2000.

MAGALHĂES, I.Discurso, ética e identidades de gênero. In: MAGALHĂES, I.; GRIGOLETTO, M.; CORACINI, M. J. (Orgs.) Práticas identitárias. Língua e discurso. Săo Carlos, SP: Claraluz, 2006, pp. 71-96.

. Letramento, intertextualidade e prática social crítica. In: (org.). Discursos e

práticas de letramento. Campinas, SP: Mercado de Letras, 2012, pp. 69-92.

MARINHO, Marildes. A escrita nas práticas de letramento acadêmico. RBLA, Belo Horizonte, v. 10, n. 2, 2010. 
MOREIRA, M.A. O mestrado (profissional) em ensino. RBPG, n. 1, jul. 2004.

RIOS, G. V. Literacy Discourses: a Sociocultural Critique in Brazilian Communities. Saarbrücken: Verlag dr. müller, 2009.

SATO, Denise Tamaê Borges. A construçáo da identidade de gênero na educaçáo inclusiva: letramento e discurso. 2013. 397 f., il. Tese (Doutorado em Linguística)-Universidade de Brasília, Brasília, 2013.

STREET, B. Literacy in theory and pratice. New York: Cambridge University Press, 1984.

. What's "new" in New Literacy Studies? Critical approaches to Literacy in theory and practice. Current issues in comparative education 5 (2), 2003, pp. 77-91.

. Os novos estudos sobre o letramento: histórico e perspectivas. In: MARINHO, M.; CARVALHO, G. T. (Org.). Cultura escrita e letramento. Belo Horizonte, MG: Editora UFMG, 2010, pp. 33-53.

Eventos de letramento e práticas de letramento: teoria e prática nos Novos Estudos do Letramento. In: MAGALHÂES, I. (org.). Discursos e práticas de letramento. Campinas, SP: Mercado de Letras, 2012, pp. 69-92.

Letramentos sociais: abordagens críticas do letramento no desenvolvimento, na etnografia e na educaçấo. Trad.: Marcos Bagno. Sáo Paulo: Parábola Editorial, 2014.

TARDIF, M. Saberes docentes e formaçăo profissional. 6. ed. Petrópolis, RJ: Vozes, 2002.

TICKS, L. K.. A identificaçăo desvelada na análise do discurso de professores de inglês em formaçăo inicial. Linguagens \& cidadania, n. 13. jan-jul 2005. Disponível em: <www. ufsm.br/linguagem_e_cidadania >. Acesso em: 30 jan. 2016.

WHITE, P. Valoraçăo - A Linguagem da Avaliaçâo e da Perspectiva. Linguagem em (Dis) curso - LemD, Tubarâo, v. 4, n. esp, pp. 178-205, 2004 